\title{
Multiple fluid-filled liver cysts presenting as acute pancreatitis in a patient with known autosomal dominant polycystic kidney disease
}

\author{
Braghadheeswar Thyagarajan, Prateek Ghatage, Sayee Sundar Alagusundaramoorthy, \\ Shil Patel
}

Department of Internal Medicine, Monmouth Medical Center, Long Branch, New Jersey, USA

\section{Correspondence to} Dr Braghadheeswar

Thyagarajan,

bragmd@gmail.com

Accepted 6 July 2016
To cite: Thyagarajan $B$, Ghatage P,

Alagusundaramoorthy SS, et al. BMJ Case Rep Published online: [please include Day Month Year] doi:10.1136/bcr-2016216051

\section{DESCRIPTION}

A 70-year-old woman with autosomal dominant polycystic kidney disease (ADPKD) presented with 3 days of progressive epigastric pain unrelated to food intake. Her history included hypertension and gastro-oesophageal reflux disease. Abdominal examination revealed a soft abdomen with normal bowel sounds, mild rebound tenderness in the epigastric region and an irregular palpable liver. Laboratory results include elevated amylase (368 IU/L, normal: 18-118 IU/L), lipase $(813 \mathrm{IU} / \mathrm{L}$, normal: $9-50 \mathrm{IU} / \mathrm{L})$ and $\mathrm{C}$ reactive protein $(182 \mathrm{mg} / \mathrm{L}$, normal: $<7 \mathrm{mg} / \mathrm{L})$. Her total bilirubin, transaminases and renal functions (creatinine of $0.92 \mathrm{mg} / \mathrm{dL}$, blood urea nitrogen of $10 \mathrm{mg} / \mathrm{dL}$ and estimated glomerular filtration rate of $>60 \mathrm{~mL} /$ min) were within normal limits and alkaline phosphatase was mildly elevated (132 U/L, normal: 25 $100 \mathrm{U} / \mathrm{L}$ ).

She was admitted to the hospital for acute pancreatitis. Her CT scan of abdomen with contrast revealed blood fluid-filled cystic lesions in her liver and multiple cystic lesions in her kidney. (figure 1). She was non-compliant in her follow-ups and she never had any abdominal imaging for more than 10 years. An MRI abdomen with contrast was carried out for further evaluation which revealed blood fluid-filled lesions in her liver (figure 2) (figure 3). It was decided that the cause of her acute pancreatitis was due to the obstructive nature of the liver cysts. Her diet was advanced as tolerated and she was eventually discharged to home

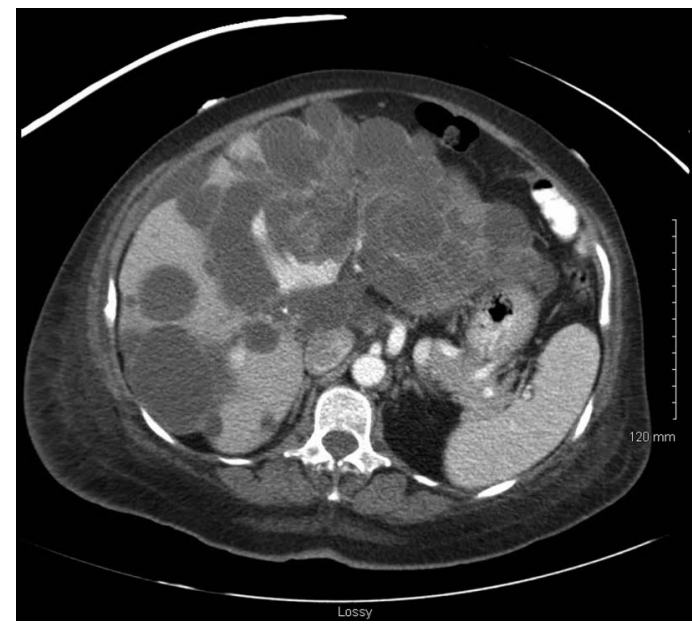

Figure 1 CT scan of the abdomen with contrast, axial view showing multiple liver cysts.

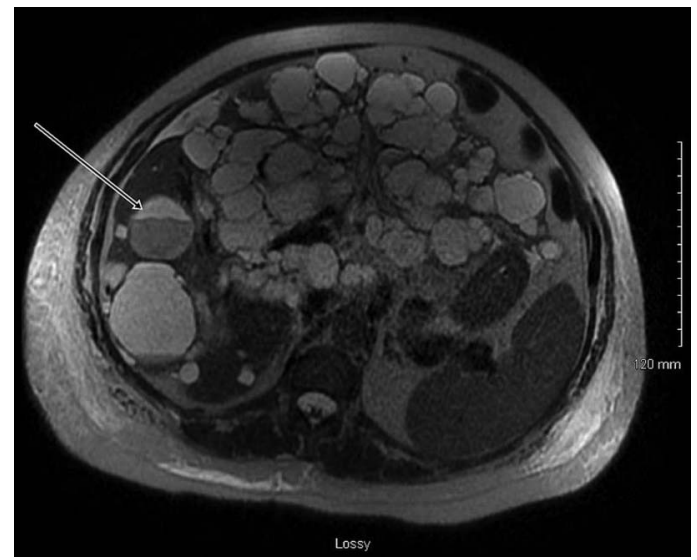

Figure 2 MRI abdomen with contrast, axial view showing multiple fluid-filled liver cysts (white arrow showing blood fluid level).

with close outpatient follow-up including periodical screening for anaemia due to her haemorrhagic cysts and also her kidney functions.

The overall prevalence of liver cysts in patients with ADPKD is $83 \%$ which increases with age reaching $94 \%$ in the age group 35-46 years. Liver cysts usually develop at a later stage than renal cysts ${ }^{1}$ Although most of the patients with liver cysts are asymptomatic, some of the complications that might occur include infection, haemorrhage, rupture, torsion, ascites, portal venous

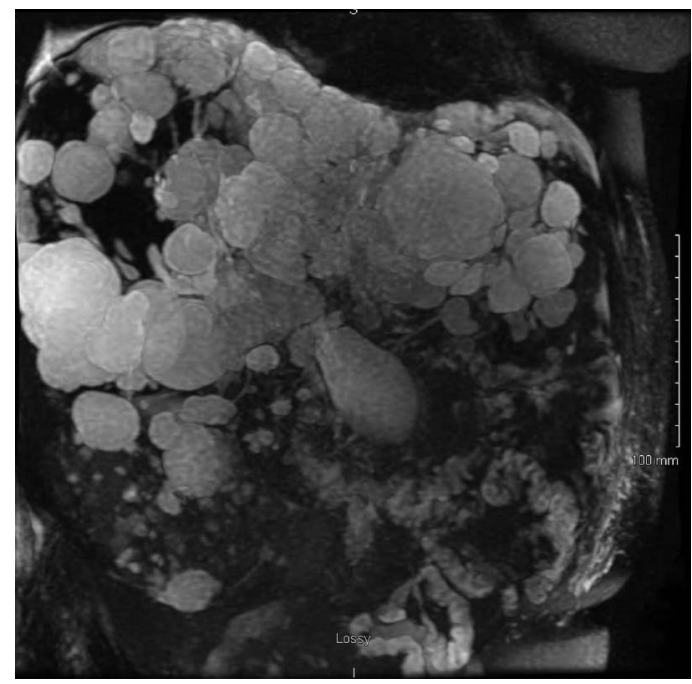

Figure 3 MRI abdomen with contrast, coronal view showing multiple liver cysts. 
hypertension, bile duct compression, hepatic vein obstruction, Budd-Chiari syndrome and progressive hepatic failure. ${ }^{2}$ Treatment options include stenting, cyst fenestration, liver resection and liver transplantation. ${ }^{3}$

\section{Learning points}

- The prevalence of liver cysts in patients with autosomal dominant polycystic kidney disease increases with age.

- Hepatic cysts are usually asymptomatic and can be managed conservatively.

- Rarely, they can present with a variety of complications such as acute pancreatitis, infection, ascites, biliary obstruction, haemorrhage, abdominal pain and portal venous hypertension in which case imaging may be helpful.
Competing interests None declared.

Patient consent Obtained.

Provenance and peer review Not commissioned; externally peer reviewed.

Copyright 2016 BMJ Publishing Group. All rights reserved. For permission to reuse any of this content visit http://group.bmj.com/group/rights-licensing/permissions.

BMJ Case Report Fellows may re-use this article for personal use and teaching without any further permission.

Become a Fellow of BMJ Case Reports today and you can:

- Submit as many cases as you like

- Enjoy fast sympathetic peer review and rapid publication of accepted articles

- Access all the published articles

- Re-use any of the published material for personal use and teaching without further permission

For information on Institutional Fellowships contact consortiasales@bmjgroup.com

Visit casereports.bmj.com for more articles like this and to become a Fellow 